\title{
Hit identification of CK2 inhibitors by methods of virtual screening
}

\author{
M. V. Protopopov ${ }^{1,2}$, S. A. Starosyla², O. V. Borovykov², V. N. Sapelkin², \\ Y. V. Bilokin', V. G. Bdzhola², S. M. Yarmoluk ${ }^{2}$ \\ ${ }^{1}$ Taras Shevchenko National University of Kyiv, \\ 4, Volodymyrska Str., Kyiv, Ukraine, 01601 \\ 2 Institute of Molecular Biology and Genetics, NAS of Ukraine \\ 150, Akademika Zabolotnoho Str., Kyiv, Ukraine, 03680 \\ ${ }^{3}$ OTAVA Ltd., \\ 400 Applewood Crescent, Unit 100, Vaughan, Ontario, L4K 0C3 Canada \\ mykola.protopopov@gmail.com
}

\begin{abstract}
Aim. To search for new CK2 inhibitors by virtual screening. Methods. Virtual screening of a small organic compounds library was performed by molecular docking using the Autodock 4.2.6 package and pharmacophore screening with the "PharmDeveloper" program. The compound activity was determined by in vitro biochemical tests using $\gamma$-P32 ATP. Results. 298 compounds were selected for biochemical testing according to the results of virtual screening. In vitro experiments showed that 18 compounds have inhibitory activity against $\mathrm{CK} 2$ with $\mathrm{IC}_{50}$ in the range of 1.4 to $20 \mu \mathrm{M}$. The active compounds belonged to 15 chemical classes. Conclusions. A number of effective CK2 inhibitors were found using molecular modeling and biochemical testing methods. LE values of these compounds were higher than 0.3 that makes these compounds excellent candidates for further drug development.
\end{abstract}

Keyword s: CK2 protein kinase, molecular docking, pharmacophore modeling, virtual screening, in vitro testing.

\section{Introduction}

Casein kinase II, CK2, is a unique protein kinase that phosphorylates serine/threonine as well as the tyrosine amino acid residues. Human CK2 is a tetrameric enzyme composed of two catalytic subunits (CK2 $\alpha$ and/or CK2 $\alpha^{\prime}$ ) and two regulatory subunits of CK2 $2 \beta$ [1]. CK2 is the most pleiotropic kinase among the protein kinase superfamily [2]. One of the explanations of such a pleiotropy may be that CK2 is present in all compartments of the cell from the nuclear to the plasma membrane, where it can interact with a large number of substrates [3, 4]. Taking into account all these facts, it is not surprisingly that CK2 is involved

(C) 2017 M. V. Protopopov et al.; Published by the Institute of Molecular Biology and Genetics, NAS of Ukraine on behalf of Biopolymers and Cell. This is an Open Access article distributed under the terms of the Creative Commons Attribution License (http://creativecommons.org/licenses/by/4.0/), which permits unrestricted reuse, distribution, and reproduction in any medium, provided the original work is properly cited 
in the regulation of the most important processes in the cell and organism: proliferation and survival [5], apoptosis [6], angiogenesis [7], DNA damage and repair [8], ER stress response [9], regulation of the carbohydrate metabolism [10]. Recent studies have reported a critical role of CK2 in embryogenesis and cell differentiation [11].

Additionally, the researchers showed the involvement of CK2 in the development of a number of pathologies, in particular cancer [12], Alzheimer's disease [13], even viral infections [14]. Therefore, CK2 may be a potential therapeutic target [15].

Almost all CK2 inhibitors block the ATPacceptor site. Benzoimidazoles, anthraquinones, flavonoids, coumarins, and pyrazolotriazines are the most represented families of CK2 inhibitors [16]. Nowadays, only one of them - CX-4945 passed the second stage of clinical trials [17].

The department of Medicinal Chemistry of Institute of Molecular Biology and Genetics NASU is developing, including search, optimization, synthesis and biological evaluation, new inhibitors of CK2 as well as inhibitors of other enzymes for during at least 10 years. Among them, there are many perspective classes, such as 3-carboxy-4(1H)-quinolone derivatives [18], 4,5,6,7-tetrahalogeno-1Hisoindole-1,3(2H)-diones [19], flavone derivatives $[20,21]$ and (thieno[2,3-d]pyrimidine4-ylthio)carboxylic acid derivatives [22, 23].

The aim of this work was to search for new CK2 inhibitors using virtual screening (molecular docking and pharmacophore screening) of the collection of the Department of Medicinal Chemistry comprising more than 150,000 compounds.

\section{Materials and methods}

\section{Molecular docking}

Preparation of ligand and receptor molecules. Autodock 4.2.6 programs package was used for the receptor-based flexible docking [24]. Ligands were prepared by Vega ZZ (command line) [25] and MGL Tools 1.5.6 [24]. The incoming formats of receptor and ligands data were converted into PDBQT-format with Vega $\mathrm{ZZ}$ in AUTODOCK force field. This format contains the coordinates of the atoms and partial charges. Hydrogen atoms were removed from nonpolar atoms. The receptor was prepared using MGL Tools and AutoGrid [24].

\section{Table 1. Docking parameters}

\begin{tabular}{|l|l|}
\hline \multicolumn{1}{|c|}{ Parameter } & Value \\
\hline Translation step & $2 \AA$ \\
Quaternion step & $50^{\circ}$ \\
Torsion step & $50^{\circ}$. \\
Torsional degrees of freedom and & $2 / 0.274$ \\
coefficient & $2 \AA$ \\
Cluster tolerance & 1000 \\
External grid energy & 0 \\
Max initial energy & 10000 \\
Max number of retries & 300 \\
Number of individuals in population & 850000 \\
Maximum number of energy evaluations & 27000 \\
Maximum number of generations & 1 \\
Number of top individuals to survive & 0,02 \\
to next generation & 0,8 \\
Rate of gene mutation & arithmetic \\
Rate of crossover & 0 \\
Mode of crossover & 1 \\
Alpha parameter of Cauchy distribution \\
Beta parameter Cauchy distribution \\
Number of Lamarckian Genetic Algorithm \\
(LGA) runs & 50 \\
\hline
\end{tabular}


We have used docking parameters reported earlier [26]. They are shown in table 1.

Flexible docking. The catalytic subunit of protein kinase CK2 complex with a stable analogue of ATP (PDB code 3NSZ) was used as a target for docking [27]. Water molecules, ions, and ligands were removed from the PDB file.

\section{Pharmacophore modeling}

Pharmacophore modeling was carried out using "PharmDeveloper" programs (conversion of models and screening collection of compounds to the required formats, pharmacophore screening, rescoring of results) [28] and Discovery Studio Visualizer 4.0 (constructing pharmacophore models) (http://accelrys.com/).

Development of pharmacophore models. Two pharmacophore models were used for pharmacophore screening. These models were constructed based on the model developed in our previous study [28]. It included a donor $(\mathrm{R}=1 \AA$, weight $=11)$ and an acceptor $(\mathrm{R}=$ $0.5 \AA$, weight $=13$ ) of hydrogen bond, a hydrophobic feature $(\mathrm{R}=1 \AA$, weight $=13)$ and an aromatic feature with directed vector $(\mathrm{R}=$ $1.6 \AA$, weight $=14$ ). The optimized default scores for pharmacophore features are following: for aromatic features -2.9 , for hydrophobic features -2.4 , for hydrogen bond donors/acceptors -1.4 , aromatic->hydrophobic feature -1.1 . These parameters were calculated during optimization and validation of the model based on a sample of active $\left(\mathrm{IC}_{50}\right.$ less than $200 \mathrm{nM}$ ) and inactive CK2 inhibitors and were used for the derived models in this study.

In model 1 the donor was changed to the acceptor and its vector was directed to an amino group of the same amino acid (Val116) to which the donor was directed. In model 2 the hydro- phobic feature was shifted toward the phosphatebinding region for $2.1 \AA$. In order to increase the accuracy of both models, the excluded volumes were determined on the hydrogen atoms of the amino acid residues of the CK2 ATPbinding site (for all $\mathrm{R}=1.2 \AA$, weight $=1$ ).

Pharmacophore screening and rescoring. The developed pharmacophore models were converted from *.chm format which is used in the Accelrys Discovery Studio Visualizer to *.query format.

The screening library was converted to the special format of "PharmDeveloper" program. 250 conformers were generated for each compound and 100 steps of optimization were performed. Further pharmacophore screening of this base was carried out against both developed models.

The rescoring of results was made automatically during screening. The rescoring function is based on the weights, radii, default scores and comparing the values of the molecular descriptors of the investigated ligands with the parameters of such descriptors of known inhibitors of the studied molecular target. These parameters include the mean deviation and the average value of each descriptor and the special correction coefficients. They were calculated on the basis of the sample of known CK2 inhibitors described above.

After rescoring, the compounds were ranked and the best ones were selected for in vitro testing.

\section{Visual analysis}

A visual analysis of the results of molecular docking (interaction of compounds with the amino acid residues of CK2 ATP-binding site) and the results of the pharmacophore modeling 
was carried out in the Discovery Studio Visualizer 4.0.

\section{Technical details}

All calculations were carried out on computer cluster of the Department of Medicinal Chemistry of the Institute of Molecular Biology and Genetics of the NASU. The cluster was built using the BEOWULF technology (see Fig. 1) [29]. The BEOWULF architecture allows scaling power with increasing cluster nodes. The cluster consists of a master node and slave nodes. The master node serves as the center for assigning tasks and the storage location of the cluster file system.

Nowadays, [the] cluster of the Department of biomedical chemistry of the Institute of molecular biology and genetics of the NASU has 24 cores with a frequency of $5.2 \mathrm{GHz}$.

\section{In vitro testing}

Compounds were tested using in vitro kinase assay [30]. Each test was done in triplicate in a reaction volume of $30 \mu \mathrm{L}$, containing $6 \mu \mathrm{g}$ of peptide substrate RRRDDDSDDD (New England Biolabs); 10 units of recombinant human CK2 holoenzyme (New England Biolabs);

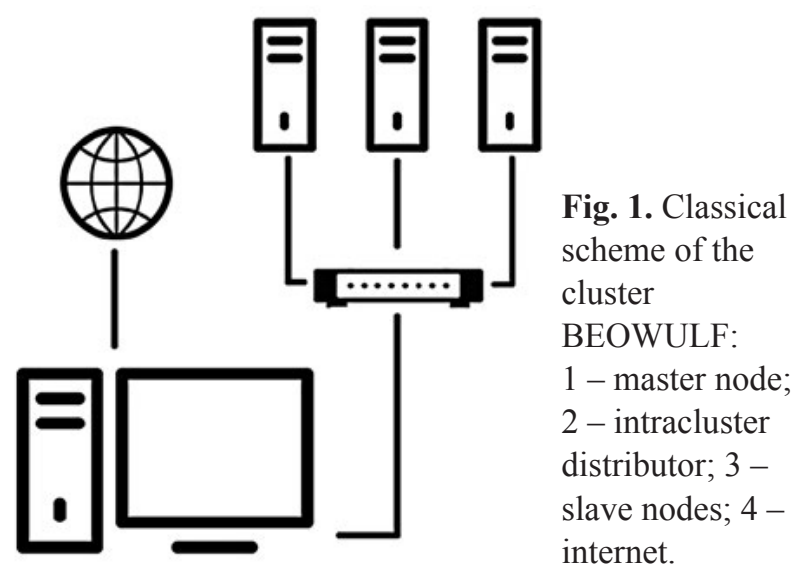

$50 \mu \mathrm{M}$ ATP and $\gamma$-labeled ${ }^{32} \mathrm{P}$ ATP, diluted to specific activity of $100 \mu \mathrm{Ci} / \mu \mathrm{M}$; CK2 buffer (20 mM Tris-HCl, pH 7.5; $50 \mathrm{mM} \mathrm{KCl;} 10 \mathrm{mM}$ $\mathrm{MgCl} 2$ ) and inhibitor in varying concentrations. Incubation time was $20 \mathrm{~min}$ at $30^{\circ} \mathrm{C}$. The reaction was stopped by adding $10 \mu \mathrm{L} 5 \%$ o-phosphoric acid and the reaction mixture was loaded onto 20-mm discs of phosphocellulose paper (Whatman). Disks were washed three times with $1 \%$ o-phosphoric acid solution, air-dried at room temperature and counted by the Cherenkov method in a beta-counter (LKB). As a negative control an equal volume of DMSO was added to the reaction mixture. The inhibition percent was calculated as a ratio of substrate-incorporated radioactivity in the presence of inhibitor to the radioactivity incorporated in control reactions, i.e. in the absence of inhibitor. Serial dilutions of inhibitor stock solution were used to determine its $\mathrm{IC}_{50}$ concentration.

\section{Results and Discussion}

Combinatorial library of more than 150,000 organic compounds was used for virtual screening (molecular docking and pharmacophore screening) towards human CK2.

258 compounds for in vitro testing were selected using molecular docking and pharmacophore modeling followed by visual exception. According to the results of in vitro testing [,] 18 compounds showed inhibitory activity with $\mathrm{IC}_{50}$ values in the range from 1.4 to $20 \mu \mathrm{M}$. Structures and $\mathrm{IC}_{50}$ of the tested compounds are shown in Table 2.

18 compounds are referred to 15 chemical classes of inhibitors. 9 compounds were found using molecular docking and 9 - using pharmacophore screening. 9 compounds (1a, $\mathbf{2}, \mathbf{3}$, $8,10,12,13,14,15)$ have $\mathrm{IC}_{50}$ less than $5 \mu \mathrm{M}$. 
9 compounds found during pharmacophore screening were additionally docked into the ATP-binding site of CK2 to study their binding to the kinase active site. The binding modes of these compounds corresponded almost completely to the binding modes which were the

Table 2. Structure, $\mathbf{I C}_{\mathbf{5 0}}, \mathbf{L E}$ and physicochemical properties of studied compounds

\begin{tabular}{|c|c|c|c|c|c|c|c|c|c|c|c|}
\hline Scaffold & Compound & Structure & $\begin{array}{c}\mathrm{IC}_{50} \\
\mu \mathrm{M}\end{array}$ & LE* & $\begin{array}{l}\text { Heavy } \\
\text { atom ** }\end{array}$ & MW & \#HD & \#HA & $\# \mathrm{RB}$ & cLogP & cLogS \\
\hline 1 & 1a & & 2.5 & 0.3 & 26 & 368 & 2 & 2 & 5 & 3.9 & -6.8 \\
\hline 1 & $1 b$ & & 7.9 & 0.27 & 26 & 385 & 2 & 2 & 5 & 4.4 & -7.3 \\
\hline 2 & 2 & & 1.4 & 0.21 & 38 & 503 & 3 & 8 & 5 & 3.8 & -7.2 \\
\hline 3 & 3 & & 5 & 0.29 & 25 & 369 & 1 & 5 & 3 & 3.4 & -5.1 \\
\hline 4 & 4 & & 14.4 & 0.26 & 26 & 348 & 3 & 6 & 3 & 2.7 & -3.8 \\
\hline
\end{tabular}

*LE - ligand efficiency. **Heavy atom - number of non-hydrogen atoms. 


\begin{tabular}{|c|c|c|c|c|c|c|c|c|c|c|c|}
\hline Scaffold & Compound & Structure & $\begin{array}{c}\mathrm{IC}_{50} \\
\mu \mathrm{M}\end{array}$ & LE* & $\begin{array}{l}\text { Heavy } \\
\text { atom } * *\end{array}$ & MW & \#HD & \#HA & \#RB & $\operatorname{cLog} \mathrm{P}$ & cLogS \\
\hline 5 & $5 a$ & & 6.9 & 0.24 & 29 & 430 & 2 & 5 & 5 & 3 & -5.9 \\
\hline 5 & $5 b$ & & 12.6 & 0.25 & 27 & 400 & 2 & 4 & 3 & 3.2 & -6 \\
\hline 6 & 6 & & 5.6 & 0.29 & 25 & 374 & 2 & 5 & 6 & 3.2 & -5.5 \\
\hline 7 & 7 & & 15.8 & 0.3 & 22 & 308 & 1 & 3 & 4 & 4.3 & -5.7 \\
\hline 8 & 8 & & 3 & 0.42 & 18 & 315 & 2 & 4 & 2 & 2.5 & -2.2 \\
\hline 9 & 9 & & 20 & 0.26 & 25 & 391 & 0 & 4 & 3 & 3.6 & -5.6 \\
\hline 10 & 10 & & 2 & 0.26 & 30 & 477 & 4 & 4 & 6 & 4.7 & -7.2 \\
\hline
\end{tabular}


Hit identification of CK2 inhibitors by methods of virtual screening

\begin{tabular}{|c|c|c|c|c|c|c|c|c|c|c|c|}
\hline Scaffold & Compound & Structure & $\begin{array}{c}\mathrm{IC}_{50}, \\
\mu \mathrm{M}\end{array}$ & LE* & $\begin{array}{l}\text { Heavy } \\
\text { atom ** }\end{array}$ & MW & \#HD & \#HA & \#RB & cLogP & cLogS \\
\hline 11 & $11 \mathrm{a}$ & & 5.5 & 0.45 & 16 & 254 & 2 & 4 & 4 & 2 & -3.6 \\
\hline 11 & 116 & & 11 & 0.45 & 15 & 220 & 1 & 3 & 3 & 1.5 & -3.5 \\
\hline 12 & 12 & & 3 & 0.28 & 27 & 383 & 2 & 6 & 5 & 2.5 & -4.9 \\
\hline 13 & 13 & & 2.7 & 0.32 & 24 & 339 & 1 & 5 & 4 & 2.8 & -4.7 \\
\hline 14 & 14 & & 3.7 & 0.26 & 29 & 389 & 3 & 8 & 5 & 2.8 & -5.2 \\
\hline 15 & 15 & & 2.19 & 0.35 & 22 & 372 & 1 & 3 & 2 & 4.4 & -5.5 \\
\hline
\end{tabular}

basis of pharmacophore models. The most active four compounds obtained from pharmacophore modeling are shown in Fig. 2 (mapping with the corresponding pharmacophore models) and in Fig. 3 (docking results).

In Fig. 3 the binding modes of found compounds with the ATP-acceptor site of CK2 are shown. The binding modes were obtained by Autodock 4.2.6. The compounds had typical binding modes of the type I protein kinases inhibitors. All compounds had a hydrogen bond with the amino acid residues of the hinge region (Val116 and/or Glu114). Compound 3 (Fig. 3b) formed a hydrogen bond with the Asp175 in phosphate-binding pocket. Compounds 8 and 13 (Fig. 3 c,e) formed hydrogen bonds with Asn118 and additionally fixed the molecule in the active site. The main 
feature of binding modes of all compounds is a large number of hydrophobic interactions with the amino acid residues of the ATPbinding site: Val66. Val53. Phe113. Ile174. Ile95. Met163. $\pi-\pi$ interaction with hydrophobic amino acid residue Phe113 also significantly contributed to stabilizing the inhibitor in the CK2 active site.

Notably, the physicochemical properties of the studied inhibitors are in accordance with the Lipinski's rules, which makes the compounds suitable for further research and development of potential drugs. Additionally, parameter LE (ligand efficiency) was used to estimate the contribution of each atom to the compound activity. It is measured in $\mathrm{Kcal} / \mathrm{mol} /$ number of heavy atoms. LE is also an important indicator of lead-likeness for further optimization studies. Remarkably, several com- pounds had LE indices greater than 0.3 (see Table 2), which is a widely accepted lower limit, in particular, values $0.3,0.3,0.42,0.45$, $0.45,0.32$ were obtained for compounds 1a, $7,8,11 \mathrm{a}, 11 \mathrm{~b}$ and 13 . Therefore, some of these compounds may be agood starting point for the development of new effective and specific CK2 inhibitors.

\section{Conclusions}

As a result of virtual screening of the 150,000 small-organic compounds library a series (18 compounds) of CK2 inhibitors were found. $\mathrm{IC}_{50}$ of studied inhibitors ranged from 1.4 to $20 \mu \mathrm{M}$. These 18 inhibitors belonged to 15 scaffolds. Correspondence of all compounds to drug-like properties and high values of LE for compounds 7. 8. 11a and 11b (0.3. 0.42. 0.45 . $0.45 \mathrm{Kcal} / \mathrm{mol} / \mathrm{number}$ of heavy atoms.

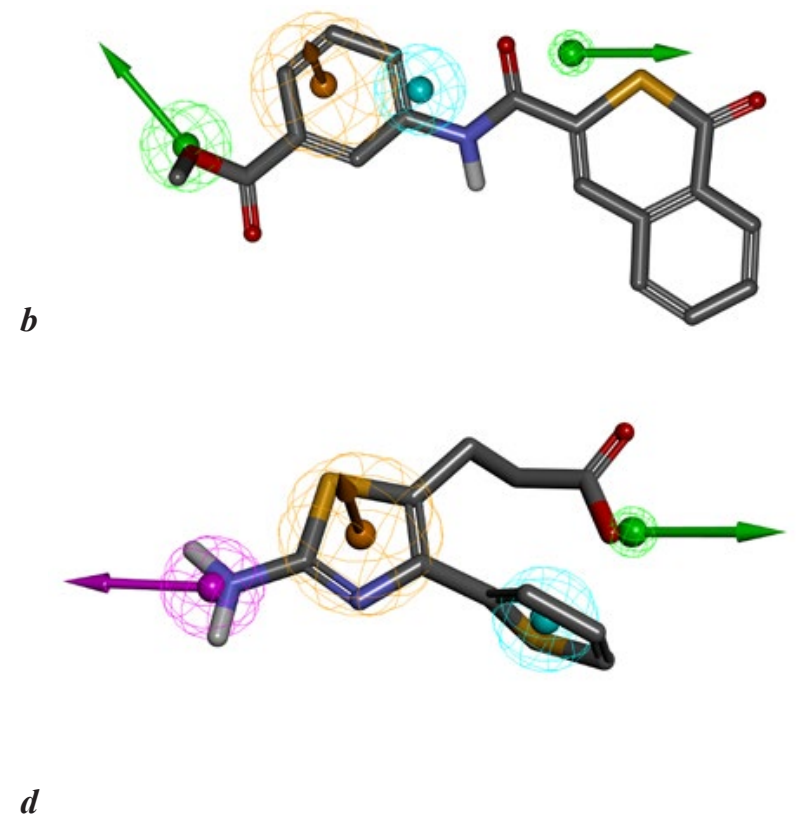

c

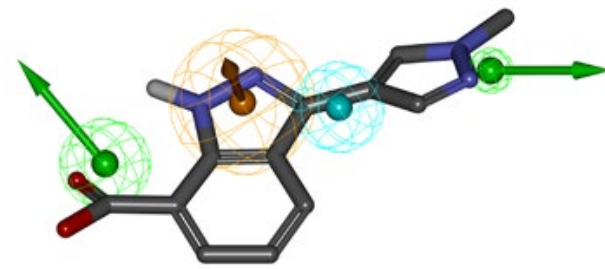

$a$

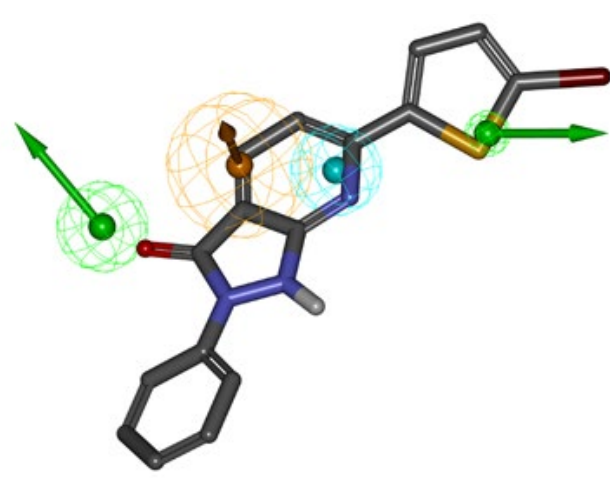

Fig. 2. Mapping compounds 8 (a). 13 (b). 15 (c) to pharmacophore model 1. compound 11a (d) to pharmacophore model 2. Pharmacophore features are labeled with green (H-bond acceptor), purple (H-bond donor), orange (aromatic) and cyan (hydrophobic) colors. 


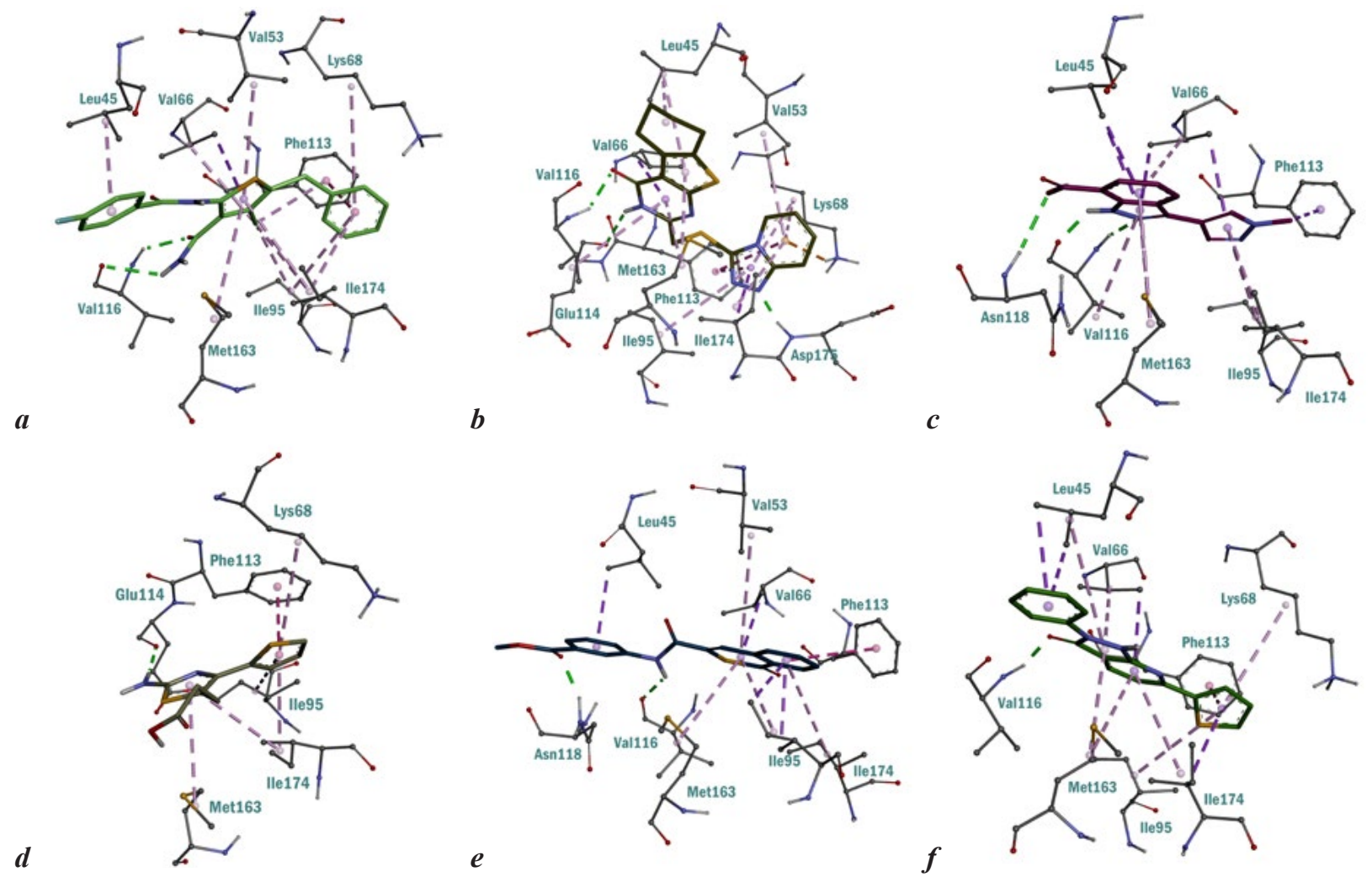

Fig. 3. The complexes of compounds 1 (a). 3 (b). 8 (c). 11a (d). 13 (e) and 15 (f) with ATP-acceptor site of CK2. Hbonds are shown by green dashed lines, hydrophobic interactions - purple dashed lines.

respectively) make these compounds excellent candidates for further development of effective CK2 inhibitors and potential drugs.

\section{Funding}

This work was supported by a grant from the National Academy of Sciences of Ukraine №0112U004110.

\section{REFERENCES:}

1. Raaf J, Brunstein E, Issinger $O G$, Niefind $K$. The interaction of CK2alpha and CK2beta, the subunits of protein kinase CK2, requires CK2beta in a preformed conformation and is enthalpically driven. Protein Sci. 2008;17(12):2180-6.
2. Bian $Y$, Ye $M$, Wang $C$, Cheng $K$, Song $C$, Dong $M$, Pan Y, Qin H, Zou H. Global screening of CK2 kinase substrates by an integrated phosphoproteomics workflow. Sci Rep. 2013;3:3460.

3. Faust M, Jung M, Günther J, Zimmermann R, Montenarh $M$. Localization of individual subunits of protein kinase CK2 to the endoplasmic reticulum and to the Golgi apparatus. Mol Cell Biochem. 2001;227(1-2):73-80.

4. Faust M, Montenarh M. Subcellular localization of protein kinase CK2. A key to its function? Cell Tissue Res. 2000;301(3):329-40.

5. St-Denis NA, Litchfield $D W$. Protein kinase CK2 in health and disease: From birth to death: the role of protein kinase CK2 in the regulation of cell proliferation and survival. Cell Mol Life Sci. 2009;66(1112):1817-29. 
6. Ahmad KA, Wang G, Unger G, Slaton J, Ahmed K. Protein kinase CK2--a key suppressor of apoptosis. Adv Enzyme Regul. 2008;48:179-87.

7. Montenarh M. Protein kinase CK2 and angiogenesis. Adv Clin Exp Med. 2014;23(2):153-8.

8. Montenarh $M$. Protein kinase CK2 in DNA damage and repair. Transl. Cancer Res. 2016; 5(1): 49-63.

9. Götz C, Montenarh M. Protein kinase CK2 in the ER stress response. Adv Biol Chem. 2013; 3(3A): 1-5.

10. Al Quobaili F, Montenarh M. CK2 and the regulation of the carbohydrate metabolism. Metabolism. 2012;61(11):1512-7.

11. Götz C, Montenarh M. Protein kinase CK2 in development and differentiation. Biomed Rep. 2017; 6(2):127-133.

12. Chua MM, Ortega CE, Sheikh A, Lee M, AbdulRassoul H, Hartshorn KL, Dominguez I. CK2 in Cancer: Cellular and Biochemical Mechanisms and Potential Therapeutic Target. Pharmaceuticals (Basel). 2017;10(1). pii: E18.

13. Rosenberger AF, Morrema TH, Gerritsen WH, van Haastert ES, Snkhchyan H, Hilhorst R, Rozemuller AJ, Scheltens P, van der Vies SM, Hoozemans JJ. Increased occurrence of protein kinase CK2 in astrocytes in Alzheimer's disease pathology. J Neuroinflammation. 2016;13:4.

14. St-Denis NA, Litchfield DW. Protein kinase CK2 in health and disease: From birth to death: the role of protein kinase CK2 in the regulation of cell proliferation and survival. Cell Mol Life Sci. 2009;66(1112):1817-29.

15. Trembley JH, Chen Z, Unger G, Slaton J, Kren BT, Van Waes $C$, Ahmed $K$. Emergence of protein kinase CK2 as a key target in cancer therapy. Biofactors. 2010;36(3):187-95.

16. Cozza $G$. The Development of CK2 Inhibitors: From Traditional Pharmacology to in Silico Rational Drug Design. Pharmaceuticals (Basel). 2017;10(1). pii:E26.

17. Pierre F, Chua PC, O'Brien SE, Siddiqui-Jain A, Bourbon P, Haddach M, Michaux J, Nagasawa J, Schwaebe MK, Stefan E, Vialettes A, Whitten JP, Chen TK, Darjania L, Stansfield R, Bliesath J, Drygin D, Ho C, Omori $M$, Proffitt $C$, Streiner $N$, Rice $W G$, Ryckman DM, Anderes $K$. Pre-clinical characterization of CX-4945, a potent and selective small molecule inhibitor of CK2 for the treatment of cancer. Mol Cell Biochem. 2011;356(1-2):37-43.

18. Golub AG, Yakovenko OY, Bdzhola VG, Sapelkin VM, Zien P, Yarmoluk SM. Evaluation of 3-carboxy$4(1 \mathrm{H})$-quinolones as inhibitors of human protein kinase CK2. J Med Chem. 2006;49(22):6443-50.

19. Golub AG, Yakovenko OY, Prykhod'ko AO, Lukashov SS, Bdzhola VG, Yarmoluk SM. Evaluation of 4,5,6,7-tetrahalogeno-1H-isoindole-1,3(2H)-diones as inhibitors of human protein kinase CK2. Biochim Biophys Acta. 2008;1784(1):143-9.

20. Golub AG, Bdzhola VG, Kyshenia YV, Sapelkin VM, Prykhod'ko AO, Kukharenko OP, Ostrynska OV, Yarmoluk SM. Structure-based discovery of novel flavonol inhibitors of human protein kinase CK2. Mol Cell Biochem. 2011;356(1-2):107-15.

21. Golub AG, Bdzhola VG, Ostrynska OV, Kyshenia IV, Sapelkin VM, Prykhod'ko AO, Kukharenko OP, Yarmoluk SM. Discovery and characterization of synthetic 4'-hydroxyflavones-New CK2 inhibitors from flavone family. Bioorg Med Chem. 2013;21(21): 6681-9.

22. Golub AG, Bdzhola VG, Briukhovetska NV, Balanda AO, Kukharenko OP, Kotey IM, Ostrynska OV, Yarmoluk SM. Synthesis and biological evaluation of substituted (thieno[2,3-d]pyrimidin-4-ylthio)carboxylic acids as inhibitors of human protein kinase CK2. Eur J Med Chem. 2011;46(3):870-6.

23. Ostrynska OV, Balanda AO, Bdzhola VG, Golub $A G$, Kotey IM, Kukharenko OP, Gryshchenko AA, Briukhovetska NV, Yarmoluk SM. Design and synthesis of novel protein kinase CK2 inhibitors on the base of 4-aminothieno[2,3-d]pyrimidines. Eur J Med Chem. 2016;115:148-60.

24. Morris GM, Huey R, Lindstrom $W$, Sanner $M F$, Belew RK, Goodsell DS, Olson AJ. AutoDock4 and AutoDockTools4: Automated docking with selective receptor flexibility. J Comput Chem. 2009;30(16): 2785-91.

25. Pedretti A, Villa L, Vistoli G. VEGA--an open platform to develop chemo-bio-informatics applications, using plug-in architecture and script programming. J Comput Aided Mol Des. 2004;18(3):167-73.

26. Syniugin AR, Ostrynska OV, Chekanov MO, Volynets GP, Starosyla SA, Bdzhola VG, Yarmoluk SM. Design, synthesis and evaluation of 3-quinoline car- 
boxylic acids as new inhibitors of protein kinase CK2. J Enzyme Inhib Med Chem. 2016;31(sup4):160-169. 27. Ferguson AD, Sheth PR, Basso AD, Paliwal S, Gray K, Fischmann TO, Le HV. Structural basis of CX-4945 binding to human protein kinase CK2. FEBS Lett. 2011;585(1):104-10.

28. Starosyla SA, Volynets GP, Protopopov MV, Bdzhola $V G$, Yarmoluk SM. The development of algorithm for pharmacophore model optimization and rescoring of pharmacophore screening results. Ukr Bioorg Acta. 2016; 14(1):24-34.

29. Sterling T, Becker DJ, Savarese D, Dorband JE, Ranawake UA, Packer $C V$. BEOWULF: A parallel workstation for scientific computation. Proceedings of the 24th International Conference on Parallel Processing. Oconomowoc. WI. 1995; 11-14.

30. Hastie C, McLauchlan H, Cohen P. Assay of protein kinases using radiolabeled ATP: a protocol. Nat. Protoc. 2006; 1(2): 968-971.

\section{Ідентифікація сполук-хітів - інгібіторів СК2 методами віртуального скринінгу.}

М. В. Протопопов, С. А. Старосила,

О. В. Боровіков, В. М. Сапелкін, Я. В. Білокінь,

В. Г. Бджола, С. М. Ярмолюк.

Мета. Пошук нових інгібіторів протеїнкінази СК2. Методи. Віртуальний скринінг бібліотеки низькомолекулярних сполук проводили методами молекулярного докінгу, програмним пакетом Autodock 4.2.6 та фармакофорного моделювання - програмою «PharmDeveloper». Активність інгібіторів визначали у біохімічних тестах in vitro (із використанням $\gamma$-P32 АТФ). Результати. Віртуальним скринінгом було відібрано 298 сполук для біохімічного тестування. Експерименти in vitro показали, що 18 сполук проявляють інгібувальну активність щодо СК2 із $\mathrm{IC}_{50}$ в межах від 1.4 до $20 \mu \mathrm{M}$. Активні сполуки належать до 15 хімічних класів. Висновки. За допомогою методів молекулярного моделювання та біохімічного тестування було знайдено ряд інгібіторів CK2, що мали показник LE вище 0.3 та $є$ перспективними для подальшої оптимізації з метою створення лікарських засобів на їхній основі.

К л ю ч о в і с л о в а: протеїнкіназа СК2, молекулярний докінг, фармакофорне моделювання, віртуальний скринінг, in vitro тестування.

\section{Идентификация хит-соединений - ингибиторов СК2 методами виртуального скрининга.}

Н. В. Протопопов, С. А. Старосила, А. В. Боровиков, В. Н. Сапелкин, Я. В. Белоконь, В. Г. Бджола, С. М. Ярмолюк.

Цель. Поиск новых химических соединений со способностью ингибировать протеинкиназу СК2. Методы. Виртуальный скрининг библиотеки низкомолекулярных органических соединений осуществляли при помощи методов молекулярного докинга программным пакетом Autodock 4.2.6 и фармакофорного моделирования - программой «PharmDeveloper». Активность ингибиторов изучали при помощи биохимических тестов in vitro, используя $\gamma$-Р32 АТФ). Результаты. Виртуальным скринингом было отобрано 298 соединений для биохимического тестирования. Эксперименты in vitro показали, что 18 соединений ингибируют протеинкиназу СК2 в диапазоне значений $\mathrm{IC}_{50}$ от 1.4 до $20 \mu \mathrm{M}$. Активные соединения принадлежат 15 химическим классам. Выводы. Используя методы молекулярного моделирования и биохимического тестирования было обнаружено ряд ингибиторов протеинкиназы СK2, со значением LE выше 0.3, которые являются перспективными для последующей оптимизации для разработки на их основе лекарственных средств.

К л юч е в ы е с л о в а: протеинкиназа СК2, молекулярный докинг, фармакофорное моделирование, виртуальный скрининг, in vitro тестирование.

Received 01.05.2017 